the numbers in individual groups were too small to allow a multivariate analysis. Unfortunately, six serum samples that were repeatedly positive in the enzyme immunoassay could not be tested by the recombinant immunoblot assay. However, even on the most cautious assumption - that the sample from the one heterosexual subject would have been confirmable by the recombinant immunoblot assay, and that the samples from the five homosexual subjects would not have been confirmable-the association of homosexuality with confirmed positivity for $\mathrm{C} 100$ antibody would remain significant $(p<0 \cdot 05)$.

If the antibody reactivity represents a specific antibody response to prior infection with hepatitis $C$ virus then it seems that most patients whose serum samples contained $\mathrm{C} 100$ antibody and were available for testing with the 5 ' non-coding region primers contained virus. The detection of virus in most serum samples from the homosexual men studied in which antibody was detected may imply that hepatitis $\mathrm{C}$ virus is maintained within this group largely by transmissions from chronically infected people. The failure in some cases of the primers based on coding regions to detect this virus is further confirmation of the genetic variability of the virus. It is important that further studies of patterns of viraemia should take this into account when sequence targets for amplification are being chosen. With the use of the non-coding primers, the prevalence of viraemia in our patients compares with that observed in haemophiliac patients: those whose serum contains $\mathrm{C} 100$ antibody are commonly viraemic (unpublished data). There are few data at present to indicate different outcomes of hepatitis $C$ virus infection depending upon the viral dose or route of transmission, or both.

We have shown an unequivocal association between C100 antibody and male homosexuality in patients attending a genitourinary medicine clinic. The biology of hepatitis $\mathrm{C}$ virus infection in this group of patients does not differ from that seen in post-transfusion hepatitis and in haemophiliac patients. Although detection of hepatitis $C$ virus RNA by the polymerase chain reaction is an invaluable test for identifying the patient who remains a carrier, an assay for detecting circulating viral antigens would be a useful adjunct and be more suitable for screening and large scale studies. Assays for detecting antibodies to proteins other than $\mathrm{Cl} 100$ are also desirable for elucidating more completely the clinical course and epidemiology of hepatitis C virus infection.

RJCG was supported by the clinical research and development committee of University College and Middlesex School of Medicine. We thank colleagues at Wellcome Diagnostics and the North London Blood Transfusion Centre for helpful discussions; Sarah Jacob and Phil Tuke for technical assistance; and Peter Williams for statistical assistance.

1 Alter MJ, Coleman PJ, Alexander WJ, et al. Importance of heterosexual activity in the transmission of hepatitis $B$ and non-A, non-B hepatitis. fAMA 1989;262:1201-5.

2 Choo QL, Kuo G, Weiner AJ, Overby LR, Bradley DW, Houghton $M$. Isolation of a cDNA clone derived from a blood borne non-A, non-B viral hepatitis genome. Science 1989;244:359-62.

3 Kuo G, Choo QL, Alter HJ, et al. An assay for circulating antibodies to a major etiologic virus of human non-A, non-B hepatitis. Science 1989;244:362-4.

4 Garson JA, Tedder RS, Briggs $M$, et al. Detection of hepatitis C viral sequences in blood donations by "nested" polymerase chain reaction and sequences in blood donations by "nested" polym

5 Esteban JI, Esteban R, Viladomiu L, et al. Hepatitis $C$ virus antibodies among risk groups in Spain. Lancet 1989;ii:294-7.

6 Mortimer PP, Cohen BJ, Litton PA, et al. Hepatitis C virus antibody. Lancet 1989;ii:798

7 Melbye M, Biggar RJ, Wantzin P, Krogsgaard K, Ebbesen P, Becker NG. Sexual transmission of hepatitis $C$ virus: cohort study (1981-9) among European homosexual men. BMF 1990;301:210-2.

8 Loveday C, Pomeroy L, Weller IVD, et al. Human immunodeficiency viruses in patients attending a sexually transmitted disease clinic in London, 1982-7. BMf 1989;298:419-22.

9 Garson JA, Ring C, Tuke P, Tedder RS. Enhanced detection by PCR of hepatits C virus RNA. Lancet 1990;336:878-9.

10 McFarlane IG, Smith HM, Johnson PJ, Bray GP, Vergani D, Williams R. Hepatitis $C$ virus antibodies in chronic active hepatitis: pathogenetic factor or false positive result? Lancet 1990;335:754-7.

(Accepted 10 April 1991)

\title{
Association between infection with Helicobacter pylori and risk of gastric cancer: evidence from a prospective investigation
}

\author{
D Forman, D G Newell, F Fullerton, J W G Yarnell, A R Stacey, N Wald, F Sitas
}

\begin{abstract}
Objective-To investigate the association between gastric cancer and prior infection with Helicobacter pylori.

Design-Case-control comparison of prevalence of IgG antibodies to $H$ pylori in blood samples collected prospectively, before diagnosis of gastric cancer in the cases. Presence of $\boldsymbol{H}$ pylori antibody $(>10 \mu \mathrm{g} \mathrm{IgG} / \mathrm{ml})$ determined by enzyme linked immunosorbent assay (ELISA).

Subjects -29 men with a subsequent diagnosis of gastric cancer and 116 aged matched controls selected from over 22000 middle aged men participating in two ongoing cohort studies (the British United Provident Association study and the Caerphilly collaborative heart disease study), who had provided blood samples during 1975-1982.

Results -20 of the 29 cases $(69 \%)$ and 54 of the 116 controls $(47 \%)$ were positive for $H$ pylori specific antibody. The median specific IgG concentration was significantly higher in the cases than controls $(90 \mu \mathrm{g} / \mathrm{ml} v 3.6 \mu \mathrm{g} / \mathrm{ml}, \mathrm{p}<0.01)$. The estimated odds ratio for the risk of gastric cancer in those with a history of infection with $\boldsymbol{H}$ pylori was $2.77(95 \%$ confidence interval 1.04 to $7.97,2 p=0.039$ ).
\end{abstract}

Conclusions-H pylori infection may be an important cause of gastric cancer; between $35 \%$ and $55 \%$ of all cases may be associated with such an infection.

\section{Introduction}

The bacterium Helicobacter pylori is a causative agent in the development of chronic antral gastritis. ${ }^{1}$ Because gastritis, when it becomes atrophic, is a condition that predisposes to precancerous changes in the stomach ${ }^{2} H$ pylori infection is also proposed to be involved in the development of gastric cancer. ${ }^{3}$ The high prevalence of $H$ pylori infection at an early age in population groups at high risk of gastric cancer ${ }^{4-6}$ supports such a hypothesis. In a recent geographical correlation study in China mortality from gastric cancer showed a significant correlation of $40 \%$ with the prevalence of antibody to $H$ pylori. ${ }^{7}$ Clinical studies based on histopathological examination of gastric biopsy specimens showed that $H$ pylori infection is more common in patients with gastric cancer than patients with no pathological lesions..$^{8-10}$

We report findings of two prospective studies in which over 22000 middle aged men in England and
Correspondence to: $\mathrm{Dr}$ BMf 1991;302:1302-5 
ICRF Cancer

Epidemiology Unit, Gibson

Building, Radcliffe

Infirmary, Oxford OX2

6HE

D Forman, PHD, senior

scientist

F Sitas, DPHIL, research

student

Department of Pathology PHLS Centre for Applied Microbiology Research,

Porton Down, Salisbury,

Wiltshire SP4 0JG

D G Newell, PHD, head of immunodiagnostics

A R Stacey, BSC, senior

microbiologist

BUPA Epidemiological

Research Group,

Department of

Environmental and

Preventive Medicine, St

Bartholomew's Hospital

Medical College, London

EC1 6BQ

F Fullerton, PHD, research

assistant

$\mathrm{N}$ Wald, FRCP, professor

MRC Epidemiology Unit (South Wales), Llandough Hospital, Penarth, South Glamorgan CF6 1XX

J W G Yarnell, MD, medical epidemiologist
Wales gave blood samples that were subsequently stored and who were followed up for the development of cancer. We compared the prevalence of $H$ pylori antibodies in blood samples from those men who subsequently developed gastric cancer with that in samples from a matched control group.

\section{Subjects and methods}

Men who developed gastric cancer were identified from the participants in two prospective cohort studies, the British United Provident Association (BUPA) study and the Caerphilly collaborative heart disease (CCHD) study. Details of these studies are available elsewhere. ${ }^{11} 12$ In brief, in the first study blood samples were obtained from 20179 men aged 35 to 64 years between 1975 and 1982 whereas in the second blood samples were obtained from 2512 men aged 45 to 59 years between 1979 and 1982. In the first study the men, who were predominantly from London and south east England, provided a blood sample while taking part in a comprehensive medical examination at the BUPA Medical Centre in London. In the second study all male residents in the appropriate age range from the south Wales town of Caerphilly had been invited to participate in an investigation into the causes of cardiovascular disease. In neither study was cancer diagnosed in any participant at recruitment. In both studies blood was collected by venepuncture and centrifuged; in the BUPA study serum was stored at $-40^{\circ} \mathrm{C}$ and in the CCHD study plasma was stored at $-20^{\circ} \mathrm{C}$. All participants were identified and flagged at the NHS central register. Any subsequent cancer registrations or deaths were notified by the register to the study organisers, together with a copy of the registration form or the death certificate, or both.

Each participant recorded with a diagnosis of gastric cancer was individually matched with four other participants who acted as controls. Controls were selected from the same study as the case; their date of birth and a date of blood sampling corresponded to within 12 months of those respective dates for the case, and blood samples were available that had undergone an identical number of freeze-thaw cycles with that of the case.

The serum and plasma samples were thawed to room temperature, mixed, and then $10 \mu \mathrm{l}$ aliquots were diluted 1:200 in 0.05 M TRIS-acetate buffer, pH $7 \cdot 6$, containing $0.01 \%$ sodium azide, $0.05 \%$ Tween 20 , and $1 \%$ bovine serum albumin. The diluted samples were then kept on ice or at $4^{\circ} \mathrm{C}$ until assayed for $H$ pylori antibodies within 96 hours. The assay was an enzyme linked immunosorbent assay (ELISA) for specific detection of $H$ pylori IgG antibodies using an acid extracted antigen. ${ }^{13}$ The assay system had been standardised and validated; with the test $93 \%$ of people with $H$ pylori present in gastric biopsy samples had antibody concentrations of $>10 \mu \mathrm{g} \mathrm{IgG/ml} \mathrm{whereas}$ $96 \%$ of people without $H$ pylori had lower concentrations. ${ }^{14}$ All samples were analysed in duplicate with positive and negative controls and a quality control sample on each ELISA plate. The assay laboratory was blind with respect to the case or control status of each sample, although each set of five samples (the case sample and the four control samples) was always assayed at the same time.

The optical density readings obtained in the test were converted into antibody concentrations with a standard curve, ${ }^{13}$ and samples with $10 \mu \mathrm{g} \mathrm{IgG} / \mathrm{ml}$ or more were classified as qualitatively positive. ${ }^{14}$ Under these conditions discriminating quantitatively between samples containing $>90 \mu \mathrm{g} \mathrm{IgG/ml} \mathrm{was} \mathrm{not} \mathrm{possible.} \mathrm{A}$ matched case-control analysis was carried out after samples had been dichotomously classified as positive or negative. A maximum likelihood estimate of the odds ratio was calculated, ${ }^{15}$ with an exact computation of the $95 \%$ confidence intervals using the EGRET statistical software package (Statistics and Epidemiology Research Corporation, Seattle, USA).

\section{Results}

Samples were available from a total of 29 men with gastric cancer, 23 from the BUPA study and 6 from the CCHD study. All had died with gastric cancer reported on their death certificates. In 16 of these men cancer registration details were also available, and for them the date of the initial registration was used as the date of diagnosis. For the remaining 13 men the date of death was used as the date of diagnosis. Information about the histopathological findings and the site of the tumour within the stomach was not available.

The mean age of the 29 cases and the 116 matched controls at the time of venepuncture was 54 years (range 41-63 years in cases and 41-64 years in controls). The mean age of the cases at diagnosis was 60 years (range 47-76 years), and cancer was diagnosed in all cases between 1980 and 1989. The interval between obtaining a blood sample and diagnosis of cancer varied between four months and 13 years and seven months (mean six years).

The figure shows the distribution of $H$ pylori antibody concentrations in the cases and controls. Twenty of the 29 cases ( $69 \%$ ) had concentrations above the cut off value for positivity of $10 \mu \mathrm{g} \mathrm{IgG} / \mathrm{ml}$. Sixteen cases $(55 \%)$ had antibody concentrations at the maximum of $90 \mu \mathrm{g} \mathrm{IgG/ml}$. Of the 116 control samples, $54(47 \%)$ were positive for antibody and $44(38 \%)$

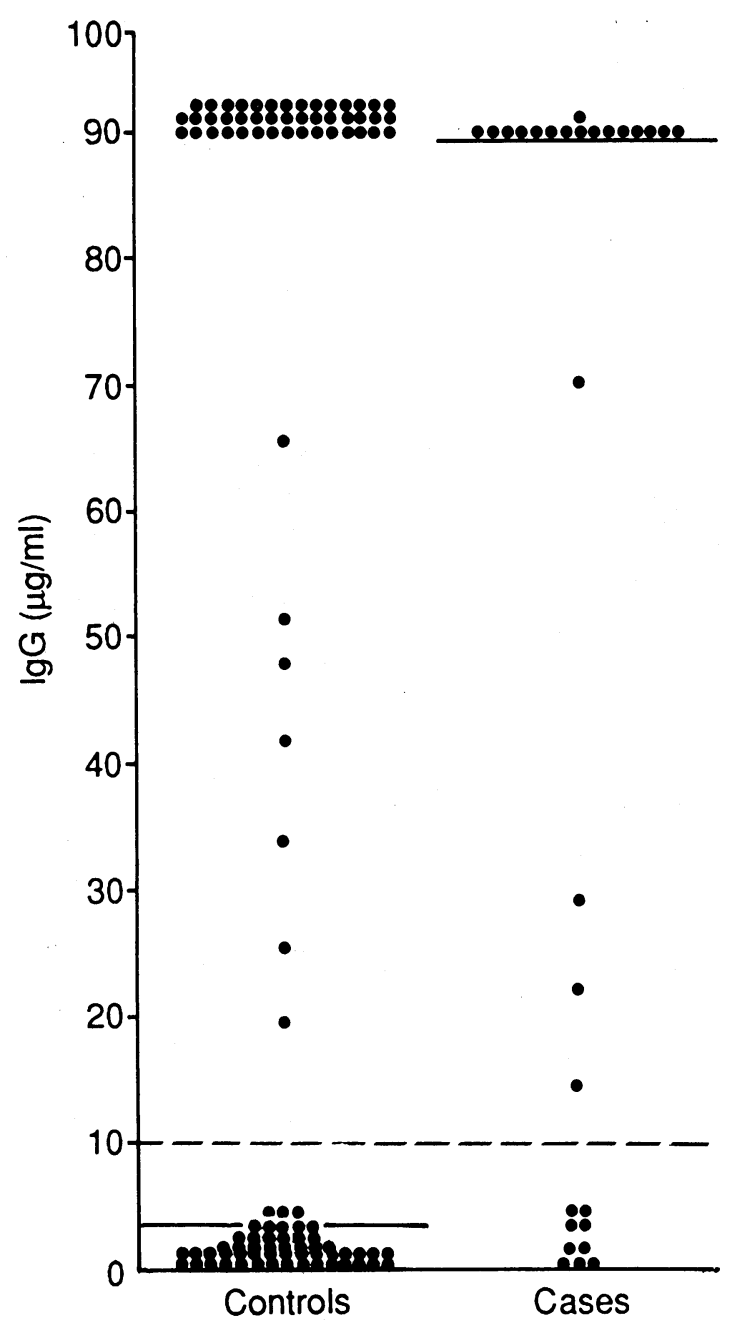

Helicobacter pylori antibody concentration ( $\mu \mathrm{g} / \mathrm{ml} \mathrm{IgG})$ in 29 cases of gastric cancer and 116 matched controls. Solid lines are median concentrations for cases $(90.0 \mu \mathrm{g} / \mathrm{ml})$ and controls $(3.6 \mu \mathrm{g} / \mathrm{ml})$, dashed line is cut off for positive response $(10.0 \mu \mathrm{g} / \mathrm{ml})$ 
showed the maximum concentration. The median concentration for the cases was at the maximum - that is, $90 \mu \mathrm{g} / \mathrm{ml}$ whereas that for the controls, $3.6 \mu \mathrm{g} / \mathrm{ml}$, was below the cut off value for positivity. A nonparametric rank test ${ }^{16}$ showed that the cases had significantly higher antibody concentrations than the controls $(\mathrm{p}<0.01)$.

The table shows the proportion of cases and controls defined as positive for $H$ pylori antibody, together with the estimated odds ratio based on a matched analysis. The overall odds ratio was significant, at $2.77(95 \%$ confidence interval 1.04 to 7.97 ) (two sided $\mathrm{p}=0.039$ ).

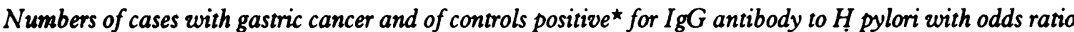
and $95 \%$ confidence interval, and according to interval between blood sample and diagnosis and according to study cohort

\begin{tabular}{|c|c|c|c|c|c|c|c|}
\hline \multirow[b]{2}{*}{ Antibody status of case } & \multicolumn{5}{|c|}{ No of controls positive for antibody } & \multirow[b]{2}{*}{ Matched odds ratio $\dagger$} & \multirow{2}{*}{$\begin{array}{l}95 \% \text { Confidence } \\
\text { interval } \neq\end{array}$} \\
\hline & $\mathbf{0}$ & 1 & 2 & 3 & 4 & & \\
\hline \multicolumn{8}{|c|}{ All subjects } \\
\hline Positive & 2 & 3 & 9 & 3 & 3 & $2 \cdot 77$ & 1.04 to 7.97 \\
\hline Negative & 1 & 4 & 4 & 0 & 0 & & \\
\hline \multicolumn{8}{|c|}{ Interval between blood sample and diagnosis of cancer } \\
\hline <5 Years: & & & & & & & \\
\hline & 1 & 2 & 1 & 2 & 2 & $2 \cdot 68$ & 0.49 to 18.69 \\
\hline $\begin{array}{l}\text { Negative } \\
\text { 5-14 Years: }\end{array}$ & 0 & 1 & 2 & 0 & 0 & & \\
\hline Positive & 1 & 1 & 8 & 1 & 1 & $2 \cdot 82$ & 0.82 to 11.35 \\
\hline Negative & 1 & 3 & 2 & 0 & 0 & & \\
\hline \multicolumn{8}{|c|}{ Study cohort } \\
\hline BUPA study: & & & & & & & \\
\hline Positive & 2 & 2 & 9 & 1 & 1 & \multirow{2}{*}{\multicolumn{2}{|c|}{$\begin{array}{r}0.99 \text { to } 9.03 \\
-\quad 5\end{array}$}} \\
\hline Negative & 1 & 4 & 3 & 0 & 0 & & \\
\hline CCHD study: & & & & & & \multirow{3}{*}{$2 \cdot 25$} & \\
\hline Positive & 0 & 1 & 0 & 2 & 2 & & 0.14 to 137.58 \\
\hline Negative & 0 & 0 & 1 & 0 & 0 & & \\
\hline
\end{tabular}

${ }^{\star} H$ pylori IgG concentration $\geqslant 10 \mu \mathrm{g} / \mathrm{ml}$. tMaximum likelihood estimate. †Exact computation. and economically homogeneous group of men in professional and managerial occupations. Subjects in the CCHD study were mainly in skilled and semiskilled manual occupations. As the controls were selected from the same study cohort this effectively matches for social class and indicates that our results are unlikely to be due to confounding. That there was a difference between the two cohorts, which may relate to social class, was shown by the prevalence of subjects with $H$ pylori antibodies among the controls: $40 \%$ in the BUPA study and $71 \%$ in the CCHD study. The respective estimates for the odds ratios based on the matched analysis $(2.86$ and 2.25$)$ were, however, similar. The difference in $H$ pylori infection rates among groups of different social class may offer an explanation for the well established social class differences in risk of gastric cancer ${ }^{20}$ rather than being a confounding factor. Barker et al have recently showed that in England and Wales overcrowding in childhood was associated with an increased risk of gastric cancer in adult life. ${ }^{21}$ They suggested that overcrowding may predispose to transmission of $H$ pylori in childhood and that this, in turn, might be a cause of the social class difference in the risk of cancer.

The prospective design of this study, with blood samples being collected before the diagnosis of cancer, reduces the possibility that the disease itself affected the chance of being infected by $H$ pylori or affected the concentration of specific antibody. The exclusion of data relating to cases in which cancer was diagnosed within five years after blood sampling did not materially affect the estimate of the odds ratio, suggesting that occult disease did not have such an effect either.

The use of an antibody test to identify prior infection may be more appropriate for this study than alternative direct methods, such as identifying $H$ pylori in cultures or histopathological examination of gastric biopsy specimens. Severe atrophy of the stomach and the formation of foci of intestinal metaplasia, both of which probably precede the development of gastric tumours, result in reduced colonisation by $H$ pylori. ${ }^{22}{ }^{23}$ In these circumstances a biopsy specimen may be negative while; for several years the IgG antibody concentration, although falling, would remain positive, correctly indicating evidence for a past infection that is no longer active.

If our estimated odds ratio of 2.77 is correct then, because of the relatively high prevalence of $H$ pylori infection in the general population, the estimate of attributable risk will also be high. Other studies showed that the prevalence of $H$ pylori infection in the population in developed countries varies between $30 \%$ and $70 \% .{ }^{24}$ Our estimated odds ratio of 2.77 means that between $35 \%$ and $55 \%$ of all gastric cancer may be attributable to $H$ pylori infection, suggesting that such infection is an important cause. Whether the worldwide decline in incidence of gastric cancer ${ }^{19}$ may be attributed, in part, to a comparable decline in the prevalence of $H$ pylori infection is not known. Although ageprevalence data may be interpreted as exhibiting a secular downward trend in $H$ pylori infection rates, ${ }^{25}$ no data are available in which $H$ pylori infection has been adequately assessed in relation to both age and calendar period.

How a person becomes infected with $H$ pylori is not yet fully understood. Neither the factors that affect the risk of a subject acquiring such infection nor methods of prophylaxis have yet been identified with any certainty. The possibility that the control of $H$ pylori infection may prevent gastric cancer will no doubt further stimulate such research.

We thank Sir Richard Doll, Dr V Beral, and Dr T Key for suggesting improvements to the manuscript, $\mathrm{Mr} \mathrm{C}$ Frost for statistical advice, and Miss $\mathrm{H}$ Powell for typing. and gastric cancer as the prevalence of both infection ${ }^{46}$ and cancer $^{19}$ is increased in populations with poor socioeconomic conditions. Most of these data are from the BUPA study, which was based on a socially 
1 Dixon MF. Campylobacter pylori and chronic gastritis. In: Rathbone BJ, Heatley RV, eds. Campylobacter pylori and gastroduodenal disease. Oxford Blackwell Scientific Publications, 1989:106-16.

2 Sipponen P, Kekki M, Siurala M. Precancerous conditions. In: Filipe MI, Jass JR, eds. Gastric carcinoma. Edinburgh: Churchill Livingstone, 1986:152-71

3 Correa P, Ruiz B. Campylobacter pylori and gastric cancer. In: Rathbone BJ Heatley RW, eds. Campylobacter pylori and gastroduodenal disease. Oxford Blackwell Scientific Publications, 1989:139-45.

4 The Gastrointestinal Physiology Working Group. Helicobacter pylori and gastritis in Peruvian patients: relationship to socioeconomic level, age and sex. Am f Gastroenterol 1990;85:819-23.

5 Perez-perez GI, Taylor DN, Bodhidatta L, Wongsrichanalai J, Baze WB Dunn BE, et al. Seroprevalence of Helicobacter pylori infections in Thailand. $\mathcal{F}$ Infect Dis 1990;161:1237-41.

6 Fox JG, Correa P, Taylor NS, Zavala D, Fontham E, Janney F, et al. Campylobacter pylori-associated gastritis and immune response in a population at increased risk of gastric carcinoma. Am $\mathcal{f}$ Gastroenterol 1989;84:775-81.

7 Forman D, Sitas F, Newell DG, Stacey AR, Boreham J, Peto R, et al. Geographic association of Helicobacter pylori antibody prevalence and gastric cancer mortality in rural China. In $f$ Cancer 1990;46:608-11.

8 Robey-Cafferty SS, Ro JY, Cleary KR. The prevalence of Campylobacter pylori in gastric biopsies from cancer patients. Modern Pathology 1989;2: pylori $473-6$.

9 Feng Y, Wang Y. Campylobacter pylori in patients with gastritis, peptic ulcer and carcinoma of the stomach in Lanzhou, China. Lancet 1988; $\mathrm{i} 1055-6$.

10 Jaskiewicz K, Louwrens HD, Woodroof LW, Van Wyk MJ, Price SK. The association of Campylobacter pylori with mucosal pathological changes in population at risk for gastric cancer. $S$ Afr Med J 1989;75:417.9.

11 Wald N, Idle M, Boreham J, Bailey A. Low serum vitamin A and subsequent risk of cancer: preliminary results of a prospective study. Lancet 1980;ii: 813-5.

12 The Caerphilly and Speedwell Collaborative Group. Caerphilly and Speedwell collaborative heart disease studies. $f$ Epidemiol Community Health 1984;38: 259-62.

13 Steer HW, Hawtin PR, Newell DG. An ELISA technique for the serodiagnosis of Campylobacter pyloridis infection in patients with gastritis and benign duodenal ulceration. Serodiagnosis and Immunotherapy 1987;1:253-9.
14 Talley NJ, Newell DG, Ormand JA, Carpenter HA, Wilson WR, Zinsmeister AR, et al. Serodiagnosis of Helicobacter pylori: a comparison of enzyme linked immunosotbent assays. 1 Clin Microbiol (in press).

15 Breslow NE, Day NE. Statistical methods in cancer research. Vol 1. The analysis of case-control studies. Lyons: International Agency for Research on Cancer,

16 Kwa G, Cleton F, Wang DY, Bulbrook RD, Bulstrode JC, Hayward JL, et al. Prospective study of plasma prolactin levels and subsequent risk of breas cancer. Br J Cancer 1981:28:673-6.

17 Talley NJ, Dimagno E, Zinsmeister AR, Perez-perez G, Blaser M. Helicobacter pylori and gastric cancer: a case-control study [abstract]. Revisto Espanola de Enfermedades Digestivas 1990;78 (suppl 1):7-8.

18 Yang PC, Davis S. Epidemiological characteristics of adenocarcinoma of the gastric cardia and distal stomach in the United States, 1973-82. Int $\mathcal{J}$ Epidemiol 1988;17:293-7.

19 Howson CP, Hiyama T, Wynder EL. The decline in gastric cancer: epidemiology of an unplanned triumph. Epidemiol Rev 1986;8:1-27.

20 Logan WPD. Cancer mortality by occupation and social class 1851-1971. London: HMSO, 1982. (Studies on Medical and Population Subjects, No 44.)

21 Barker DJP, Coggon D, Osmond C, Wickham C. Poor housing in childhood and high rates of stomach cancer in England and Wales. Br $\mathcal{Y}$ Cancer and high rates

22 Siurala M, Sipponen P, Kekki M. Campylobacter pylori in a sample of the Finnish population: relations to morphology and function of gastric mucosa. Gut 1988;29:909-15.

23 Paull G, Yardley JH. Pathology of $\mathrm{C}$ pylori-associated gastric and esophageal lesions. In: Blaser MJ, ed. Campylobacter pylori in gastritis and peptic ulcer disease. New York: Igaku-Shoin, 1989:73-97.

24 Sitas F, Forman D, Yarnell JWG, Burr ML, Elwood PC, Pedley S, et al. Helicobacter pylori infection rates in relation to age and social class in a population of Welsh men. Gut 1991;32:25-8.

25 Marshall BJ. Campylobacter pylori: its link to gastritis and peptic ulcer disease. Rev Infect Dis 1990;12 (suppl 1):S87-93.

(Accepted 17 April 1991)
Gastrointestinal Unit and Surgical Review Office, Western General Hospital, Edinburgh EH4 2XU D M Sedgwick, FRCS, research fellow

J A Akoh, FRCs, surgical registrar

I M C Macintyre, FRCS, consultant surgeon

Correspondence to: Mr Macintyre.

BMF 1991;302:1305-7

\section{Gastric cancer in Scotland: changing epidemiology, unchanging workload}

\author{
D M Sedgwick, J A Akoh, I M C Macintyre
}

\section{Abstract}

Objective-To determine the changes in incidence of and mortality from gastric cancer in Scotland between 1978 and 1987 and in the operative workload in Lothian between 1979 and 1988.

Design-Analysis of national incidence statistics for gastric cancer derived from the Scottish national cancer registry, deaths from gastric cancer recorded by the registrar general for Scotland, and Lothian surgical audit data.

Setting-Scotland and Lothian Health Board area.

Patients - Patients in Scotland with gastric cancer during 1978 to 1987 inclusive; patients in Scotland with gastric cancer recorded on their death certificate as cause of death during 1978 to 1987 ; patients who had an operation in Lothian for gastric cancer during 1979 to 1988.

Main outcome measures-Changes in incidence of and mortality from gastric cancer in Scotland from 1978 to 1987 and in the number of operations performed for gastric cancer in Lothian from 1979 to 1988.

Results - Mortality from gastric cancer in Scotland fell by about $25 \%$ over the 10 years. The incidence and standardised incidence of gastric cancer showed a marginal decline of about $9 \%$. The differences in trends between incidence and mortality were significant $(p<0.05)$.

Conclusions - This study shows that the surgical workload associated with gastric cancer is not declining. This is because the incidence has remained almost static, which may be due to the relative increase in the numbers of older people in the population, who are at greater risk of developing gastric cancer. Gastric cancer should not be regarded as a disease in decline. Incidence and workload should determine resources allocated to this disease rather than mortality statistics.

Since the 1940s mortality from gastric cancer has been falling throughout the world. This has been particularly pronounced in countries such as Finland and the United States, where, by the 1980s, the annual age adjusted mortality had fallen by $73 \%$ and $66 \%$ respectively compared with 30 years earlier. ${ }^{1}$ The incidence of gastric cancer has also been reported to be falling. ${ }^{24}$ These statistics have led to gastric cancer being viewed as a disease in decline. However, the numbers of patients in our practice with gastric cancer do not seem to be declining. ${ }^{6}$

We examined the surgical workload associated with gastric cancer in our area, the trends in the incidence of and mortality from gastric cancer in Scotland, and the implications of these data for health care provision.

\section{Methods}

In Lothian Health Board details of all general operations have been recorded since 1977 in the Lothian surgical audit scheme. ${ }^{7}$ For each procedure the surgeon codes the organ concerned, the disease process, and the nature of the operation. We examined data for 1979-88 on gastric cancer to determine the number of operations each year.

We abstracted data on the incidence of gastric cancer during 1978-87 from Scottish national cancer registration scheme records, which are held by the information and statistics division of the Scottish Health Services Common Services Agency. Population based regional registries in Edinburgh, Glasgow, Dundee, Aberdeen, and Inverness contribute data to

\section{Introduction}

